\title{
Financial Distress and Corporate Governance: The Impact of Board Configuration
}

\author{
Xavier Brédart ${ }^{1}$ \\ ${ }^{1}$ Warocqué School of Business and Economics, University of Mons, Belgium \\ Correspondence: Warocqué School of Business and Economics, University of Mons, Mons, Belgium. \\ E-mail: xavier.bredart@umons.ac.be
}

Received: January 2, 2014

Accepted: January 14, $2014 \quad$ Online Published: February 24, 2014

doi:10.5539/ibr.v7n3p72

URL: http://dx.doi.org/10.5539/ibr.v7n3p72

\begin{abstract}
The number of filings for bankruptcy procedures has exploded since 2007 and governance has been pointed out as one of the causes. We took a dataset of 312 US firms and asked the following research question: does the board of directors configuration have an impact on financial distress? We used a matched-pair sample of US quoted firms with half of the sample filing for Chapter 7 (liquidation) or 11 (reorganization) of the United States Bankruptcy Code and conducted logit regression analysis. We found that some board size was significantly different for firms that opted for legal protection from those that did not. This study uses corporate governance perspective to analyse the configuration of the board and its impact on a the decision of a company to resort to a bankruptcy protection law. By demonstrating that corporate governance matters in terms of financial distress, this study offers guidance to shareholders and financial institutions.
\end{abstract}

Keywords: corporate governance, crisis, board of directors, financial distress, bankruptcy.

\section{Introduction}

In today's business, resorting to a bankruptcy protection law is a common occurrence among U.S. corporations of all sizes and in all sectors (Altman, 1999). During the recent financial crisis, many firms fell into distress and filed for bankruptcy (Li \& Zhong, 2013). Due to the impact of this decision for many actors (e.g., financial institutions and shareholders), a major issue in the academic literature is financial distress detection. Although bankruptcy detection models have been developed since the sixties (Beaver, 1967; Altman, 1968), the huge majority of them (Fijorek \& Grotowski, 2012; Attaran et al., 2012) consider accounting and financial data only as explanatory factors. From the late 1980s through to the mid-1990s, some authors (Hambrick \& D'Aveni, 1988, 1992; Gilson, 1990; Daily \& Dalton, 1994; Gales \& Kesner, 1994) started to investigate the link between financial distress and corporate governance. Results of these studies confirm that corporate governance variables significantly improve the predictive power of widely used bankruptcy forecast models. Nevertheless, more recently, only a few studies (Donoher, 2004; Fich \& Slezak, 2008; Chang, 2009; Lajili, \& Zéghal, 2010; Platt \& Platt, 2012) have been devoted to this under-investigated part of the literature. Crisis periods represent unique opportunities to reconsider the actual governance practices, which have showed their limits during the subprimes crisis. The efficiency of governance mechanisms provided for in codes and laws, such as a greater proportion of independent directors on the board, may therefore be questioned. For instance, a study by Erkens, Hung and Matos (2010) notably reports that firms with a higher proportion of independent directors on the board performed worse during the 2007-2008 period.

As far as we know, no study linking the occurrence of bankruptcy filing and governance patterns has been carried out during the subprimes crisis. This particular context, characterized by many bankruptcy cases, makes it possible to highlight the deficiencies of corporate governance (Magnier, 2010) and their impact on financial distress.

The aim of this paper is to test the effectiveness of internal corporate governance mechanisms regarding the board of directors on the durability of American companies during the subprimes crisis. Our study may contribute to a better academic insight into the role of corporate governance during the subprimes crisis and be of interest to practitioners (managers and investors). To this end, we decided to conduct a logit analysis upon a paired sample of 312 companies previously quoted on the Amex, the Nasdaq and the NYSE. One hundred fifty-seven of these entities filed for chapter 7 (liquidation procedure) or chapter 11 (reorganization procedure) of 
the American bankruptcy code between the burst of the real estate speculative bubble in July 2007 and December 2009; the other 157 did not resort to bankruptcy protection during this timeframe. So for each of the companies that was engaged in a liquidation or reorganization procedure, there is a corresponding one in the same field of activity and of "approximately" the same size (determined by the total assets) that has not met with the same kind of financial trouble. A logit analysis of this sample will enable us to detect corporate governance mechanisms that influence the failure of firms. The results of our study show that increasing the number of directors on the board constitutes a virtuous corporate governance mechanism regarding company perennity.

The paper proceeds as follows. The second section develops working hypotheses regarding the effects of governance variables on financial distress. The third section concerns our sample and the methodology used. In the fourth section, we will comment descriptive statistics, provide results of the logit model, and conduct hypothesis testing before discussion (section 5). The last section will highlight our conclusions.

\section{The Board of Directors}

We focus on the board of directors because it is considered as the main corporate governance mechanism (Walsh \& Saward, 1990; Depret et al., 2004; Norwahida et al., 2012). We consider four internal corporate governance mechanisms; these concern the structure and organization of the board of directors: its size, independence, activity and the potential duality of the CEO as chairman.

Size of the board of directors. As per agency theory, the main argument in favor of a larger board of directors is that the increase in the number of members raises their disciplinary control over the CEO. As per resource dependence perspective, it also implies more external links (Goodstein, Gautam, \& Boeker, 1994) and a diversification of the expertise (Zahra \& Pearce, 1989). Extending the resource dependence perspective (Pfeffer $\&$ Salancik, 1978) to the context of bankruptcy, Gales and Kesner (1994) argue that the more directors there are serving on a board, the better connected the firm is to critical resources. These connections may protect the organization from adversity (Zahra \& Pearce, 1989). From an empirical point of view, studies by Chaganti et al. (1985) and Hambrick and D'Aveni (1992) and Gales and Kezner (1994), carried out on paired samples, report that boards of companies having filed for a bankruptcy protection chapter are characterized by a smaller number of directors.

We will assert our hypothesis regarding the size of the board as follows:

H1: Firms with a large number of directors on the board are less likely to experience financial distress and file for bankruptcy protection.

Independence of the board. The presence of independent directors on the board is subject to particular attention in the literature. Although several studies have been devoted to the relationship between firm performance and the presence of independent administrators on the board, the conclusions are not unanimous. As per Aglietta and Riberioux (2004), independent directors are characterized by a more superficial understanding of the specificities of the company. In contrast, according to Weisbach (1988), independent directors are in a better position to monitor the actions of the CEO. He states that as a result of their position in the firm and the existence of possible inherent contracts with the CEO, internal directors would not be as fair as independent ones. Based on agency perspective, Eisenhardt (1989) explains that the above a dependent board configuration may lead the firm's owners bearing an unreasonable amount of risk that may contribute to crisis of the firm and eventual bankruptcy. Independent directors may also be considered as a strategic resource (Mace, 1986) because they make it possible to broaden the organizational knowledge of the company (Cornett et al., 2008). Based on the rigidity perspective, Daily and Dalton (1994) argue that a dependent board of directors would exacerbate the rigidity of the company and limit the organization's adaptive abilities, and thus, its ability to respond to crises. Empirically, Elloumi and Gueyie (2001), Daily et al. (2003) and Hambrick and D'Aveni (1992) report that firms with a large proportion of independent directors show a smaller probability to file for bankruptcy. Moreover, as per Fich and Slezak (2008), studies linking board configuration to financial distress show that smaller boards with more independent or outside directors are more effective at avoiding bankruptcy. Therefore, we will propose the following hypothesis regarding the proportion of independent directors:

H2: Firms with a high proportion of independent directors on the board are less likely to experience financial distress and file for bankruptcy protection.

Board activity. Vafaes (1999), Adams (2005) and Brick and Chidambaran (2010) claim that board meeting frequency is an important dimension of board operations. As per Conger, Finegold and Lawler (1998), meetings make it possible to improve the effectiveness of the board; among other reasons, directors meeting more often are more likely to counteract the entrenchment of managers (Linck, Netter, \& Yang, 2008). In this vein, Brick 
and Chidambaran (2010) find a positive link between board activity and firm value. Jensen (1993) has doubts regarding the effectiveness of meetings because the agenda is generally set by the CEO and, so, routine tasks absorb much of the meeting time and limit opportunities for directors to exercise meaningful control over management. He also suggests that board meetings are more reactive than proactive. This suggestion is supported by results of Vafaes' (1999) and Adams' (2005) investigations stating that boards respond to poor performances by raising their level of board activity. As per Brick and Chidambaran (2008), the danger of discordance between board members increases when the firm performs poorly. This may result in an increase in the board's activity, because, inter alia, directors may want to protect themselves from being blamed for not having taken action when needed. In the context of our study, a large number of meetings the year preceding the filing for bankruptcy may reflect problems preceding bankruptcy filing. We will assert our third hypothesis as follows.

\section{H3: Board activity is positively associated with financial distress and filing for bankruptcy protection.}

Duality as CEO and chairman of the board. Holding the role of both CEO and chairman of the board of directors makes evaluating managers more difficult and increases agency costs and entrenchment risks (Fama \& Jensen, 1983; Lipton \& Lorsch, 1992; Jensen, 1993). This is because the board, being in principle the organ in charge of controlling the actions of the managers, is headed by the very object of this overseeing. That is the reason why OECD (Note 1) (2004) recommends separating the two functions. CEO duality unifies the decision-making process (Anderson \& Anthony, 1986; Brickley, Coles, \& Jarrell, 1997) but exacerbates the rigidity of the company and limits the organization's adaptive abilities, and thus, its ability to respond to crises (Daily \& Dalton, 1994). Moreover, as per agency perspective, CEO duality may lead to important risk taking that may result into bankruptcy (Eisenhardt, 1989).

H4: Duality as CEO and chairman is positively associated with financial distress and filing for bankruptcy protection.

\section{Methodology}

\subsection{Sample and Data}

Since many companies had to resort to bankruptcy filings, the recent context of crisis provides a unique research setting to study financial distress occurrence. As the subprime crisis started in the United States, firms quoted on American markets have logically been the first ones to be impacted. For this reason, we decided to conduct our analysis in this area.

The sample used in this study consists of 312 firms originally quoted on the Amex, the Nasdaq and the NYSE from mid-2007 to 2009, covering the first part of the subprimes crisis as per Bordes and Clerc (2011). Among the 25,093 requests for chapter 7 or 11 recorded on these markets during this 30-month period, 156 transferred their quotation on an Over-The-Counter (OTC) market. This data is sourced from the Bloomberg database. Thus, 156 of the 312 firms of our sample filed for chapter 7 or 11 of the United States Bankruptcy Code and transferred their quotation on an OTC market during this timeframe. Next, we utilised Bloomberg to collect accounting data. Data related to governance has been collected from SEC DEF 14A proxy statements preceding the filing for bankruptcy. We then obtained a matched pair of financially healthy companies (without any filing for bankruptcy protection law during the timeframe). Using a decision tree designed for the pairing of this data (see appendix 1), we matched industry (SIC code) and firm size (total assets). The final sample includes 312 firms.

\subsection{Measures}

Dependent Variable. A dichotomous qualitative dependent variable is commonly used for bankruptcy prediction models (Ohlson, 1980; Premachandra, Bhabra, \& Sueyoshi, 2009). We utilise one dependent variable: Financial Distress For this study. Financial distress is a binary variable taking a value of 1 if the firm filed for chapter 7 or 11 of the American Bankruptcy Code and 0 otherwise.

Independent Variables. Our key explanatory variables are Board size, independence and activity and CEO duality. We measure Board size as the number of directors on the board on the latest accounting fiscal year before the filing for liquidation or reorganisation procedure. We measure Board independence as the proportion of independent directors on the board on the latest accounting fiscal year before the filing for liquidation or reorganisation procedure. We define Board activity as the number of board meetings held the latest accounting fiscal year before the filing for liquidation or reorganisation procedure. Following Boyd (1995), we use a binary variable for $C E O /$ Chairman duality which takes a value of 0 for separated $\mathrm{CEO}$ and chair roles, and 1 for a combined $\mathrm{CEO} /$ chair role on the last accounting fiscal year before the filing for liquidation or reorganisation 
procedure. Data on Board size, independence and activity and on CEO duality was obtained from DEF 14A proxy statements.

Control Variables. In order to take the impact of variables that may influence company filing into account, the model considers two control variables. Control variables are recorded on last accounting fiscal year before the filing for liquidation or reorganisation procedure as it was the case for the independent variables. We control for firm-related effects - Return On Equity $(R O E)$ and Solvency ratios. Accounting ratios show discriminant power regarding the decision to file for bankruptcy (Beaver, 1967; Altman, 1968; Ohlson, 1980; Zmijewsji, 1984). Moreover, following a review of 190 studies related to the development of bankruptcy prediction models, Du Jardin (2009) reports that $93 \%$ of them include financial ratios. According to Refait (2004), the accounting measures that have the highest discriminating power in bankruptcy analysis are the profitability and the balance sheet structure. Therefore, we introduced the following accounting ratios in our model: the ROE (Mensah, 1984) and the solvency ratios (Altman, Marco, \& Varetto, 1994). ROE is defined as net income divided by total shareholders' equity and solvency as total shareholders' equity divided by total assets. These ratios were collected from the Bloomberg database.

\subsection{Methodology}

Since our dependent variable, financial distress, is dichotomous, we use a binary logit regression model, as it is the case in many studies regarding the occurrence of bankruptcy filing (Ohlson, 1980; Mensah, 1984; Zavgren, 1985; Aziz, Emmanuel, \& Lawson, 1988; Burgstahle, Jiambalvo, \& Noreen, 1989; Flagg, Giroux, \& Wiggins, 1991; Platt \& Platt, 1991; Bell, Mossman, Swartz, \& Turtle, 1998; Premachandra, Bhabra, \& Sueyoshi, 2009). A logit model describes the relationship between a dichotomous dependent variable that can take value 1 (bankrupt business) or value 0 (healthy), and $\mathrm{k}$ other explanatory variables $\mathrm{x}_{1}, \mathrm{x}_{2} \ldots \mathrm{x}_{\mathrm{k}}$. These variables can be quantitative or qualitative. Since the dependent variable is binary (dichotomous), the latter follows the Bernoulli distribution such that $\mathrm{Pi}=\mathrm{P}(\mathrm{yi}=1)$ is the probability of bankruptcy and 1-Pi is the probability of non-failure. The estimated model requires the endogenous variable to be a linear combination of exogenous variables:

$\mathrm{yi}^{*}=\beta \mathrm{Xi}+\varepsilon \mathrm{i}$ where $\varepsilon$ is the error term and $\beta$ the vector of coefficients;

$\mathrm{yi}=1$ if $\mathrm{yi}^{*}>0$;

$\mathrm{yi}=0$ if $\mathrm{yi}^{*} \leq 0$;

The probability of non-default (a posteriori) of firm i is given by:

$$
P(y i=0)=P\left(y i^{*} \leq 0\right)=P(\beta X i+\varepsilon i \leq 0)=P(\varepsilon i \leq-\beta X i)=F(-\beta X i)=1-F(\beta X i)=1-P i
$$

Similarly, the probability of failure (a posteriori) of firm i is represented by:

$$
P(y i=1)=P\left(y i^{*}>0\right)=P(\beta X i+\varepsilon i>0)=P(\varepsilon i>-\beta X i)=1-P(\varepsilon i \leq-\beta X i)=F(\beta X i)=P i
$$

The logit model assumes that the errors follow a logistic distribution where the distribution function is: $\mathrm{F}(\mathrm{x})=(1$ $+\mathrm{e}-\mathrm{x})-1$. Therefore, it is possible to calculate the probability of non-default of firm $\mathrm{I}$ as follows: $\mathrm{P}(\mathrm{yi}=0)=$ $\mathrm{F}(-\beta \mathrm{Xi})=(1+\mathrm{e} \beta \mathrm{Xi})-1=1-\mathrm{Pi}$. Similarly, the probability of the default of firm $\mathrm{i}$ is: $\mathrm{P}(\mathrm{yi}=1)=\mathrm{F}(\mathrm{Xi} \beta)=$ $(1+\mathrm{e}-\beta \mathrm{Xi})-1=\mathrm{Pi}$

The $\beta$ coefficients will be estimated using the method of maximum likelihood.

\section{Results}

\subsection{Correlations and Descriptive Statistics}

Correlations between all variables included in the model are presented in Table 1. All correlations are under .30. Moreover, the results of the analysis of variance inflation factors (VIF) report that all the variables (independent and control) have VIF under the suggested value of 10 (see Table1). Therefore, we have no problem with multicollinearity.

Table 1. Correlation matrix

\begin{tabular}{llccccccc}
\hline & VIF & 1 & 2 & 3 & 4 & 5 & 6 & 7 \\
\hline 1 & Financial distress & & 1.00 & & & & & \\
2 & Board size & 1.02 & & 1.00 & & & \\
3 & Board independence & 1.03 & & 0.11 & 1.00 & & \\
\hline
\end{tabular}




\begin{tabular}{lllllllll}
\hline 4 & Board activity & 1.09 & 0.01 & 0.10 & 1.00 & & & \\
5 & CEO duality & 1.05 & 0.05 & 0.02 & -0.21 & 1.00 & & \\
6 & ROE & 1.01 & 0.05 & -0.04 & 0.03 & -0.04 & 1.00 \\
7 & Solvency & 1.04 & -0.02 & -0.02 & -0.18 & 0.06 & -0.05 & 1.00 \\
\hline
\end{tabular}

Table 2 reports descriptive statistics for all the variables included in the study, for the whole sample and per category (perennial and non-perennial group) as well.

Table 2. Descriptive statistics

\begin{tabular}{lcccc}
\hline & \multicolumn{2}{c}{ Total sample } & Perennial & Non-Perennial \\
\hline & Mean & Std. Dev. & Mean & 1 \\
Financial distress & 0.5 & 0.5 & 0 & 8.07 \\
Board size & 8.27 & 2.48 & 8.47 & 0.73 \\
Board independence & 0.74 & 0.15 & 0.75 & 9.93 \\
Board activity & 9.14 & 5.01 & 8.35 & 0.53 \\
CEO duality & 0.57 & 0.50 & 0.61 & -0.46 \\
ROE & -0.36 & 3.18 & -0.26 & -0.13 \\
Solvency & 0.14 & 1.19 & 0.40 & \\
\hline
\end{tabular}

Regarding our key explanatory variables, it appears that the board is smaller for financial distressed firms (8.07 directors) than for their counterparts ( 8.47 directors). On average, the number of meetings held the year before the filing for liquidation or reorganization procedure is higher for financially distressed firms. Last, the CEO is also chairman of the board in $61 \%$ of the non-perennial firms and in $53 \%$ of the perennial firms.

Regarding control variables, Table 2 highlights the fact that the solvency ratio is considerably different for the two subsamples. As expected, firms that did not resort to bankruptcy protection are clearly in a better position to face their financial obligations.

\subsection{Logit Regressions}

In this section, we briefly present the results of the logit model; the findings will be discussed in greater detail in the next section.

The results of the logistic regression is shown in Table 3. We built and then tested two models depending on the variables included. Only control variables are used in Model 1; the four main effect variables are added in Model 2.

Table 3. Logistic regression (dependent variable: financial distress)

\begin{tabular}{lcccc}
\hline \multirow{2}{*}{ Variable } & \multicolumn{2}{c}{ Model 1 } & \multicolumn{2}{c}{ Model 2 } \\
\cline { 2 - 5 } \cline { 3 - 5 } & Beta & Std. Err. & Beta & Std. Err. \\
\hline Constant & $0.67^{* * *}$ & 0.17 & $2.12^{* *}$ & 0.81 \\
Controls & & & & 0.05 \\
ROE & -0.07 & 0.05 & -0.06 & 0.47 \\
Solvency & $-2.80^{* * *}$ & 0.43 & $-3.04^{* * *}$ & \\
Direct Effects & & & $-0.15^{* *}$ & 0.06 \\
Board size & & -0.37 & 0.89 \\
Board independence & & & 0.03 & 0.03 \\
Board activity & & -0.23 & 0.27 \\
CEO duality & & & \\
\hline
\end{tabular}




\begin{tabular}{lcc}
\hline Model Chi2 & $65.98^{* * *}(2 \mathrm{df})$ & $78.18^{* * *}(6 \mathrm{df})$ \\
Sample Size & $\mathrm{N}=312$ & $\mathrm{~N}=312$ \\
Log Likelyhood & -183.27 & -177.17 \\
Prediction accuracy & $66.35 \%$ & $70.51 \%$ \\
\hline
\end{tabular}

$\dagger$ Partially significant at $\mathrm{P}<0.10 ; *$, ***** Significant at $\mathrm{P}<0.05,0.01$, and 0.001 , respectively.

Comparing the two models, we notice improvements. Indeed, the model Chi-Square value is improving between Model 1 and Model 2 (Model 1: Wald Chi2 =65.98, p <.001; Model 2: Wald Chi2 = 78.18, p <.001). Likelihood ratio tests were also run to evaluate the difference between the models. The results of these tests (see Table 4) confirm that Model 2 fits the data significantly better than the more restrictive model (Model 1). The prediction accuracy is also better in Model 2 (prediction accuracy $=70.51 \%)$ than in Model $1(66.35 \%)$.

Table 4. Likelihood ratio tests

\begin{tabular}{lll}
\hline & \multicolumn{1}{c}{ Likelihood-ratio test } \\
\hline & LR chi2 & Prob $>$ chi2 \\
Between M1 and M2 & 12.2 & 0.0159 \\
\hline
\end{tabular}

In other words, adding governance variables (from Model 1 to Model 2) improves the model. Regarding control variables, solvency ratio (model $2: \mathrm{b}=-3.04, \mathrm{p}<.001$ ) is significant. Higher solvency ratio has a negative impact on the probability of filing for a bankruptcy chapter. Regarding direct effects, in Model 2, H1, which suggested that Board size had a negative impact on financial distress probability, is supported (Model 2: $\mathrm{b}=-0.15, \mathrm{p}<.01$ ). $\mathrm{H} 2$ is not supported. The relationship between Board independence and financial distress is not significant. H3 posited a positive relationship between Board activity and the probability to file for a bankruptcy law; H3 is not supported at 5\% threshold. Lastly, the relationship between CEO/chairman duality and financial distress is not significant.

The findings are discussed in greater detail in the next section.

\section{Discussion and Conclusions}

This study contributes to corporate governance literature by examining the role of board configuration on the occurrence of financial distress event. Using a dataset of 312 firms, we built a matched pair sample of US quoted companies that filed for reorganisation/liquidation and those who did not. We also examined the differences in board characteristics through a logit model. Our results indicate that the inclusion of corporate governance variables improves the model. We also found that board size was negatively related to financial distress. This result supports our prediction. By demonstrating that corporate governance issues could increase the accuracy of the prediction model, the results of our study add to the body of literature regarding financial distress detection. Our evidence that board size positively impacts company perennity is in line with results of previous empirical studies (Chaganti et al., 1985; Hambrick \& D’Aveni, 1992; Gales \& Kezner, 1994). According to agency theory, the increase in the number of members may have raised their disciplinary control over the CEO. Moreover, large boards have virtuous effects on the diversification of the expertise (Zahra \& Pearce, 1989) and the existence of external links (Goodstein, Gautam, \& Boeker, 1994). These connections may have protected the organization from financial distress (Zahra \& Pearce, 1989). The hypotheses related to the impact of board independence and activity and CEO duality/chairman on the occurrence of financial distress did not lead to significant results. The absence of significance regarding the influence of these variables, some of which are emblematic of corporate governance laws and codes, on company perennity constitutes an argument in favor of the inefficiency (Erkens et al., 2010) of the content of corporate governance laws and codes during the current crisis.

There are some limitations to this study. Firstly, it would have been better to have more precise information regarding the reasons for the filing for reorganisation/liquidation of our sample of firms. Further studies may be use a dataset including more detailed information regarding the financial and commercial difficulties that lead these firms to file for bankruptcy chapters of the United States Bankruptcy Code. Secondly, since the subprime banking crisis originated in the US, our study was US-centric. As per, Aguilera and Jackson (2003), governance environments differ among countries. It could be interesting to analyze the impact of boards across different governance environments. 
There are theoretical and managerial implications of this research. This study contributes to the literature as the inclusion of governance variables has made it possible to improve the prediction model. For shareholders and managers, this study reports that board characteristics affect the probability of financial distress occurrence. We clearly demonstrate that firms need to pay close attention to the size of the board of directors. Our study may help shareholders establish governance mechanisms preventing financial distress or simply to realise their investment choices. Financial institutions are obviously concerned by the risk of failure because their incomes directly depend on this.

To conclude, the results of this study lead us to conclude that board configuration do, in fact, contribute to explain the incidence of bankruptcy. The relationship between financial distress and corporate governance remains relatively poorly investigated and many research questions still need to be explored.

\section{References}

Adams, R. (2005). What do boards do? Evidence from board committee \& director compensation data. Working Paper, University of New South Wales, Sydney.

Aglietta, M., \& Rebérioux, A. (2004). Dérives du capitalisme financier. Paris: Albin Michel.

Aguilera, R. V., \& Jackson, G. (2003). The cross-national diversity of corporate governance: Dimensions \& determinants. Academy of Management Review, 28, 447-465.

Altman, E. (1968). Financial ratios, discriminant analysis \& the prediction of corporate bankruptcy. The Journal of Finance, 23(4), 589-609. http://dx.doi.org/10.1111/j.1540-6261.1968.tb00843.x

Altman, E. (1999). Bankruptcy \& distressed restructurings: Analytical issues \& investment opportunities. Washington DC: Beard Books.

Altman, E. I., Marco, G., \& Varetto, F. (1994). Corporate distress diagnosis: Comparisons using linear discriminant analysis \& neural networks. Journal of Banking \& Finance, 18(3), 505-529. http://dx.doi.org/10.1016/0378-4266(94)90007-8

Anderson, C. A., \& Anthony, R. N. (1986). The New Corporate Directors: Insights for Board Members \& Executives. New York: Whiley.

Attaran, N., Hosseini, S., Hossein, S., \& Karami, G. (2012). Bankruptcy prediction, accounting variables and economic development: empirical evidence from Iran. International Business Research, 5(8), 147-152.

Aziz, A., Emmanuel, D., \& Lawson, G. (1988). Bankruptcy prediction: an investigation of cash flow based $\begin{array}{lllll}\text { models. Journal of } & \text { Management }\end{array}$ http://dx.doi.org/10.1111/j.1467-6486.1988.tb00708.x

Beaver, W. (1967). Financial ratios as predictors of failures. Journal of Accounting Research, Empirical Research in Accounting: Selected Studies 1966, 71-111.

Bell, G. G., Mossman, C. E., Swartz, L. M., \& Turtle, H. (1998). An empirical comparison of bankruptcy models. Financial Review, 33(2), 35-54. http://dx.doi.org/10.1111/j.1540-6288.1998.tb01367.x

Bordes, C., \& Clerc, L. (2012). La BCE: quel(s) scénario(s) de sortie de crise? Revue d'Économie Financière, 103, 117-144.

Boyd, B. (1995). CEO Duality \& Firm Performance: A Contingency Model. Strategic Management Journal, 16(4), 301-312. http://dx.doi.org/10.1002/smj.4250160404

Brick, I. \& Chidambaran, N. K. (2008). Board monitoring, firm risk \& external regulation. Journal of Regulatory Economics, 33, 87-116. http://dx.doi.org/10.1007/s11149-007-9045-9

Brickley, J. A., Coles, J. L., \& Jarrell, G. (1997). Leadership structure: Separating the CEO \& chairman of the board. Journal of Corporate Finance, 3(3), 189-220. http://dx.doi.org/10.1016/S0929-1199(96)00013-2

Burgstahler, D., Jiambalvo, J., \& Noreen, E. (1989). Changes in the Probability of Bankruptcy \& Equity Value. Journal of Accounting \& Economics, 11, 207-224. http://dx.doi.org/10.1016/0165-4101(89)90006-2

Chaganti, R., Mahajan, V., \& Sharma, S. (1985). Corporate board size, composition \& corporate failures in retailing industry. Journal of Management Studies, 22(4), 400-417. http://dx.doi.org/10.1111/j.1467-6486.1985.tb00005.x

Chang, C. (2009). The corporate governance characteristics of financially distressed firms: Evidence from Taiwan. Journal of American Academy of Business, 15(1), 125-132. 
Conger, J., Finegold, D., \& Lawler, E. (1998). Appraising Boardroom Performance. Harvard Business Review, 76(1), 136-148.

Cornett, M., Marcus, A., \& Tehranian, H. (2008). Corporate governance \& pay-for-performance: the impact of earnings management. Journal of Financial Economics, 87(2), 357-373. http://dx.doi.org/10.1016/j.jfineco.2007.03.003

Daily, C., \& Dalton, D. (1994). Corporate governance \& the bankrupt firm: an empirical assessment. Strategic Management Journal, 15(8), 643-654. http://dx.doi.org/10.1002/smj.4250150806

Daily, C., Dalton, D., \& Cannella, A. (2003). Corporate governance: decades of dialogue \& data. The Academy of Management Review, 28(3), 371-382.

Depret, M-H., Finet, A., Hamdouch, A., Labie, M., Missonier-Piera, F., \& Piot, C. (2005). Gouvernement d'entreprise: enjeux managériaux et financiers. Brussels: De Boeck.

Donoher, W. J. (2004). To file or not to file? Systemic incentives, corporate control, \& the bankruptcy decision. Journal of Management, 30(2), 239-262. http://dx.doi.org/10.1016/j.jm.2003.02.003

Du Jardin, P. (2009). Bankruyptcy prediction models: how to choose the most relevant variables? Bankers, Markets \& Investors, 98(1), 39-46.

Eisenhardt, K. (1989). Agency theory: an assessment \& review. Academy of Management Review, 14, 57-74.

Elloumi, F., \& Gueyie, J. P. (2001). Financial distress \& corporate governance. Corporate Governance, 1(1), 15-23. http://dx.doi.org/10.1108/14720700110389548

Erkens, D., Hung, M., \& Matos, P. (2010). Corporate governance in the 2007-2008 financial crisis: evidence from financial institutions worldwide. Working Paper, ECGI Finance.

Fama, E. F., \& Jensen, M. C. (1983). Separation of ownership \& control. Journal of Law \& Economics, 26(2), 301-326. http://dx.doi.org/10.1086/467037

Fich, E., \& Slezak, S. (2008). Can corporate governance save distressed firms from bankrtupcy? An empirical analysis. Review of Quantitative Finance \& Accounting, 30(2), 225-251. http://dx.doi.org/10.1007/s11156-007-0048-5

Fijorek, K., \& Grotowski, M. (2012). Bankruptcy prediction: some results from a large sample of Polish companies. International Business Research, 5(9), 70-77. http://dx.doi.org/10.5539/ibr.v5n9p70

Flagg, J. C., Giroux, G. A., \& Wiggins, C. E. (1991). Predicting corporate bankruptcy using failing firms. Review of Financial Studies, 1(1), 67-78.

Gales, L. M., \& Kesner, I. F. (1994). An analysis of board of director size \& composition in bankrupt organizations. Journal of Business Research, 30(3), 271-282. http://dx.doi.org/10.1016/0148-2963(94)90057-4

Gilson, S. (1990). Bankruptcy, boards, banks, \& blockholders. Journal of Financial Economics, 27(2), 355-387. http://dx.doi.org/10.1016/0304-405X(90)90060-D

Goodstein, J., Gautam, K., \& Boeker, W. (1994). The effect of board size \& diversity on strategic change. Strategic Management Journal, 15(3), 241-250. http://dx.doi.org/10.1002/smj.4250150305

Hambrick, D., \& D’Aveni, R. (1992). Top team deterioration as part of the downward spiral of large corporate bankruptcies. Management Science, 38(10), 1445-1466. http://dx.doi.org/10.1287/mnsc.38.10.1445

Hambrick, D., \& D'Aveni, R. (1988). Large corporate failures \& downward spirals. Administrative Science Quarterly, 33, 1-23. http://dx.doi.org/10.2307/2392853

Jensen, M. (1993). The modern industrial revolution, exit, \& the failure of internal control systems. The Journal of Finance, 48(3), 831-880. http://dx.doi.org/10.1111/j.1540-6261.1993.tb04022.x

Lajili, K., \& Zeghal, D. (2010). Corporate Governance \& Bankruptcy Filing Decisions. Journal of General Management, 35(4), 3-26.

Li, Y., \& Zhong, Z. (2013). Investing in chapter 11 stocks: Trading, value, \& performance. Journal of Financial Markets, 16, 33-60. http://dx.doi.org/10.1016/j.finmar.2012.09.006

Linck, J., Netter, J., \& Yang, T. (2008). The determinants of board structure. Journal of Financial Economics, 87, 308-328. http://dx.doi.org/10.1016/j.jfineco.2007.03.004

Lipton, M., \& Lorsch, J. W. (1992). A modest proposal for improved corporate governance. Business Law, 48(1), 
59-77.

Mace, M. (1986). Directors: myth \& reality. Boston: Harvard Business School Press.

Magnier, V. (2010). La gouvernance des sociétés cotées face à la crise: pour une meilleure protection de l'intérêt social. Paris: Lextenso.

Mensah, Y. M. (1984). An examination of the stationarity of multivariate bankruptcy prediction models: a methodological study. Journal of Accounting Research, 22(1), 380-395. http://dx.doi.org/10.2307/2490719

Norwahida, S., Shin, O., \& Shaari, M. (2012). Do the board of director's characteristics affect firm performance? Evidence from Malaysian public listed companies. International Business Research, 5(9), 120-127.

Ohlson, J. (1980). Financial ratios \& the probabilistic prediction of bankruptcy. Journal of Accounting Research, 18(1), 109-131. http://dx.doi.org/10.2307/2490395

Pfeffer, J., \& Salancik, G. R. (1978). The External Control of Organizations: A Resource Dependence Perspective. New York, Harper \& Row.

Platt, H. D., \& Platt, M. B., (1991). A note on the use of industry-relative ratios in bankruptcy prediction. Journal of Banking \& Finance, 15(6), 1183-1194. http://dx.doi.org/10.1016/0378-4266(91)90057-S

Platt, H., \& Platt, M. (2012). Corporate board attributes \& bankruptcy. Journal of Business Research, 65, 1139-1143. http://dx.doi.org/10.1016/j.jbusres.2011.08.003

Premachandra, I. M., Bhabra, G. S., \& Sueyoshi, T. (2009). DEA as a tool for bankruptcy assessment: a comparative study with logistic regression technique. European Journal of Operational Research, 193(2), 412-424. http://dx.doi.org/10.1016/j.ejor.2007.11.036

Refait, C. (2004). La prévision de la faillite fondée sur l'analyse financière de l'entreprise: un état des lieux. Economie et Prévision, 162(1), 129-147.

Vafaes, N. (1999). Board meeting frequency \& firm performance. Journal of Financial Economics, 53(1), 113-142. http://dx.doi.org/10.1016/S0304-405X(99)00018-5

Walsh, J. P., \& Seward, J. K. (1990). On the efficiency of internal \& external corporate control mechanisms. Academy of Management Review, 15(3), 421-458.

Weisbach, M. (1988). Outside directors \& CEO turnover. Journal of Financial Economics, 20, 431-460. http://dx.doi.org/10.1016/0304-405X(88)90053-0

Zahra, S., \& Pearce, A. (1989). Boards of directors \& corporate financial performance: A review \& integrative model. Journal of Management, 15(2), 291-334. http://dx.doi.org/10.1177/014920638901500208

Zavgren, C. (1985). Assessing the vulnerability of failure of American industrial firms: a logistic analysis. $\begin{array}{lllll}\text { Journal of Business } \quad \text { Finance } \& \text { Accounting, } & \text { 12(1), }\end{array}$ http://dx.doi.org/10.1111/j.1468-5957.1985.tb00077.x

Zmijewski, M. (1984). Methodological issues related to the estimation of financial distress prediction models. Journal of Accounting Research, 22, 59-82.

\section{Note}

Note 1. OECD stands for Organization for Economic Co-operation and Development.

\section{Copyrights}

Copyright for this article is retained by the author(s), with first publication rights granted to the journal.

This is an open-access article distributed under the terms and conditions of the Creative Commons Attribution license (http://creativecommons.org/licenses/by/3.0/). 